\title{
Rodzina jako środowisko wychowawcze w czasach nowożytnych, red. K. Jaku- biak, Bydgoszcz 1995, Wydawnictwo Uczelniane WSP, ss. 303
}

Prezentowana tu praca zbiorowa powstała jako plon obrad konferencji Rodzina jako srodowisko wychowawcze $w$ czasach nowożytnych - koncepcje teoretyczne i praktyka (3 - 4.04.1995 r.), zorganizowanej przez K. Jakubiaka i zespół Katedry Historii Wychowania. Zgromadziła ona około 50 naukowców z całego kraju, przede wszystkim historyków i historyków wychowania oraz pedagogów, którzy interesują się wychowaniem $w$ rodzinie $i$ jego dziejami.

Obszerna publikacja (ponad 27 arkuszy drukarskich, które ze względów oszczędnościowych tworzą objętośc tylko 300 stron druku) dotyczy różnych aspektów wychowania w rodzinie oraz rodziny jako środowiska wychowawczego w XIX oraz XX wieku na ziemiach polskich. Ksiazzkę otwierają teksty wprowadzające, podkreślające między innymi range tematyki rodzinnej w badaniach historycznych oraz pedagogicznych, tak ważnych w okresie generaInych zmian społeczno-kulturalno-gospodarczych w Polsce (wypowiedzi wiceprezydenta Bydgoszczy St. Pastuszewskiego i Rektora WSP w Bydgoszczy prof. A. Tchorzewskiego; Wstęp).

Pod względem chronologicznym wyróżnić można zespół kilku artykułów dotyczących okresu do początków XIX w., w tym tak kompetentnych autorów, jak L. Mokrzecki i D. Żołądź. Tak, jak w każdym z następnych zespolów, dotyczą one zarówno praktyki, jak i zapatrywań teoretycznych (tu St. Staszica) oraz głównych warstw społecznych: szlachty, magnaterii i mieszczaństwa. Jeden $z$ istotnych walorów tych tekstów stanowi też chęć ukazania analizowanych zagadnień w ciągu rozwojowym, wykazania zmian i przyczyn ich wystapienia.

Liczniej, bo przez 10 opracowań (autorstwa m.in., K. Adamczyka, J. Hellwiga, A. Stopińskiej-Pająk, K. Wróbel-Lipowej; część ich zatrącała także o wiek XX), reprezentowany był okres zaborów, wiek XIX. Dotyczyły one wszystkich zaborów, ale nieco więcej uwagi poświęcono terenom Prus i zaboru austriackiego.
Inną dominantą stało się wychowanie patriotyczne, narzucające się jako temat znaczący czasów utraty niepodległości. Od dawna zresztą eksploatowano to zagadnienie, co byc może wypaczyło jednostronnie obraz wychowania i kształcenia czasów zaborów. W naszym zbiorze rozpraw często wiązano wychowanie patriotyczne $\mathrm{z}$ religijnym $\mathrm{i}$ taka perspektywa badawcza wydaje się najnośniejsza. Niepokoi z kolei pewne przecenianie problemów narodowych u badaczy związanych $\mathrm{z}$ terenami pogranicza i zajmujących się wychowaniem patriotycznym. Jednostronność $\mathbf{i}$ angażowanie się emocjonalne w badania i analizę ich wyników nie służą bowiem rzetelnej analizie i trzeźwej ocenie prezentowanych zagadnien. Pocieszające jest natomiast wykroczenie poza tradycyjne źródła informacji o praktyce i teorii wychowania, np. sięgnięcie do źródel pamiętnikarskich czy nawet kalendarzy odbijających przecież potoczną wiedzę, zdroworozsądkowe podejście do wychowania na miarę czasów, w których powstały, tym samym oddające poziom świadomości rodziców, zasięg teorii i oddziaływań ideologiczno-instytucjonalnych.

Reszta spośród 40 artykułów analizowanego tomu (m.in. T. Jałmużny, W. Jamrożka, K. Jakubiaka, D. Koźmian) dotyczy wychowania w rodzinie okresu międzywojennego oraz lat powojennych, przechodząc w rozważania bardziej pedagogiczne, choć nasycone treściami historycznymi. Ujęcia wynikające ze specyfiki poszczególnych źródeł łączą się z kryteriami socjologicznymi (np. środowiska małomiasteczkowe), rozważania o ideologiach wychowawczych $\mathrm{z}$ analiza naukowych stanowisk wobec wychowania rodzinnego. Ciągłość między historią a dniem dzisiejszym może uprzytomnić czytelnikowi zarówno kontynuacje, jak i zmienność wychowania $w$ rodzinie $i$ rodziny jako środowiska wychowawczego.

Tom materiałów konfarencyjnych, który tu analizuję sam w sobie stanowi pewną całość, korzystnie - jak sądzę - zróżnicowaną tematycznie, chronologicznie i metodologicznie. Stanowi on jednak tylko ogniwo $w$ ciagu pub- 
likacji związanych z rolą wychowawczą rodziny w przeszłości. Przygotowujemy następne prace monograficzne i zbiorowe dotyczące rodziny jako środowiska wychowawczego oraz wychowania rodzinnego. Istotnym ich dopetnieniem powinny stać się specjalistyczne bibliografie oraz wybory źródeł. Należy także myśleć nad formą szerszego propagowania wyników specjalistycznych badań w postaci syntez „do czytania", co postuluje m.in. w ostatnim artykule tomu Antoni Smołalski.

Juliusz Jundzill

\section{Rodzina w spoleczeństwach antycznych i wczesnym chrześcijaństwie. Literatura, prawo, epigrafika, sztuka, red. J. Jundzill, Bydgoszez 1995, Wydawnictwo WSP, ss. 346}

Zbiór artykułów, wydany pod redakcja Juliusza Jundziłla, stanowi prezentacje materiałów z konferencji naukowej nt.: Rodzina $i$ jej funkcjonowanie w kulturach Grecji i Rzymu (Wyższa Szkoła Pedagogiczna w Bydgoszczy, 4 -5 maja 1995). Praca „Rodzina w spoleczeństwach antycznych i wczesnym chrześcijaństwie. Literatura, prawo, epigrafika, sztuka", ukazująca problematyke rodziny starożytnej $\mathrm{z}$ perspektywy różnych specjalności badawczych, uzupehniła literaturę polskiego nurtu badań nad rodziną w przeszlości.

Zbiór 25 rozpraw, poświęconych rodzinie - jej funkcji wychowawczej, strukturze i roli w społeczeństwie antycznym, omawia szeroki kontekst historyczno-społeczny i kulturalny tego zagadnienia utrwalonego przez starożytnych w literaturze, prawie, epigrafice i sztuce. To bogactwo różnorodnych źródeł stanowi atut opracowania tematu. Pozwala na dialog historyków różnych specjalności.

Strukturę tomu wyznacza chronologia omawianych zjawisk - od czasów Grecji mykeńskiej, poprzez Grecję hellenistycznq̨, Rzym królewski, republike, po cesarstwo i wczesne chrześcijaństwo. Natomiast prezentowana problematyka sygnalizuje wiele zagadnień, ale nie do końca przejrzyście i jednoznacznie w swej ocenie buduje obraz rodziny antycznej. Niektóre z poglądów zaprezentowanych przez autorów artykułów świadczą o polemicznym charakterze wniosków z prowadzonych badań. Część materiału wymaga z kolei jeszcze dalszych analiz, zwłaszcza porównawczych.
Kulturom czasów przedrzymskich poświęcono tylko trzy artykuły (P. Dyczek, J. Rostropowicz, G. Wcisło), co jest odbiciem polskiego stanu badań historycznych nad tym okresem. Są one jednak znaczącym powiększeniem dorobku, przede wszystkim w zakresie analiz rodziny.

Część poświęconą Rzymowi otwierają artykuły silnie akcentujace aspekty prawne życia $w$ rodzinie. Jako reprezentatywna grupe wyróżnić tu należy rozprawy J. Zabłockiego, R. Pankiewicza oraz W. Mossakowskiego poświęcone funkcjonowaniu prawa w odniesieniu do wczesnej rodziny rzymskiej. Walorem tych rozważań jest nasycenie ich kontekstem kulturowym oraz religijnym rozpatrywanych zjawisk.

Wśród analiz tradycyjnych już źródeł wiedzy o rodzinie greckiej i rzymskiej pojawiła się literatura piękna - zwłaszcza aleksandryjska (wspomniany już artykuł J. Rostropowicz) oraz łacińska (w artykułach $M$. Cytowskiej, H. Szelest, I. Błaszczyk). Zaświadczona w rozprawach powszechność motywów rodzinnych w dorobku omawianych okresów dowodzi znacznego zainteresowania tą tematyka.

Dopełnienia obrazu rodziny czasów cesarstwa rzymskiego można poszukiwać u autorów artykułów - J. Jundziłła, W. Sudera, A. Ossowskiej - których łączy chronologia wykorzystanych źródel z I i II w. n.e. Pisarzy antycznych tego okresu charakteryzuje, obok potrzeby tworzenia literatury przeżyć estetycznych, pasja dydaktyczna, moralizatorska. 